\title{
EMPOWERING STUDENTS OF INTERNATIONAL CLASS PROGRAM- IAIN SALATIGA IN THE PRODUCTION OF PRAYING TUTORIAL VIDEO
}

\author{
Rifqi Aulia Erlangga, Mursid Saleh, Dwi Rukmini, Ahmad Sofwan \\ Universitas Negeri Semarang \\ 07rifqi@gmail.com,mursids@hotmail.com, \\ wiwidwirukmini@mail.unnes.ac.id,ahmadsofwan@mail.unnes.ac.id
}

\begin{abstract}
Abtract
This research is to develop one method of learning that is a video containing tutorial about praying procedures in English. The video is designed to facilitate students to understand the praying procedures as well as practice their competence in English, especially listening and speaking. Some experts and the users validated the effectiveness of the research. Those who validated are people who have competence in praying procedures, English and multimedia. Therefore, there must be three experts in this research. The users are given some questionnaires asking their opinions about the video. The sample of the research was taken from college students majoring in Communication and Islam Broadcasting in IAIN Salatiga. There were 35 students in one class. Video of praying tutorial produced through this research get good responses from students. They feel that by watching the video and see the audio and visual movements of the prayer contained in the video can make them able to remember more clearly how to do praying, especially for praying that is not done everyday.
\end{abstract}

Keywords: Praying, English, Video

\begin{abstract}
Abstrak
Penelitian ini bertujuan untuk mengembangkan suatu alat bantu pembelajaran yang berupa video tutorial tata cara ibadah ber-Bahasa Inggris. Video ini dirancang untuk mempermudah siswa dalam memahami tata cara beribadah sekaligus melatih kemampuan siswa dalam ber-Bahasa Inggris, khususnya listening dan speaking. Pengujian efektifitas pencapaian tujuan penelitian dilakukan dengan cara validasi para abli dan uji coba bagi pengguna. Validator adalah orang yang kompeten dalam bidang tata cara ibadah, kompeten dalam bidang Bahasa Inggris dan kompeten dalam bidang multimedia, sehingga diperlukan tiga validator didalam penelitian ini. Uji coba bagi pengguna dilakukan dengan memberikan kuesioner bagi pengguna mengenai persepsi mereka terbadap video ini. Sample yang diambil pada penelitian ini adalah mahasiswa program khusus jurusan Komunikasi dan Penyiaran Islam di IAIN Salatiga sebanyak 1 kelas yang berisi 35 siswa. Video tutorial tata cara ibadah mendapat tanggapan yang baik dari siswa. Mereka merasa dengan melihat video dan melihat gerakan audio dan visual dari doa yang terkandung dalam video dapat membuat mereka mampu mengingat lebih jelas bagaimana melakukan berdoa, terutama untuk berdoa yang tidak dilakukan setiap hari
\end{abstract}

Kata Kunci: Ibadah, Bahasa Inggris, Video

Permalink/DOI: http://dx.doi.org/10.18326/infsl3.v10i2.427-450 


\section{Introduction}

"And I did not create the jinn and mankind except to worship Me. (QS. 51:56)" Praying is not only set by God to people, it is more to people's needs since God doesn't need anything from the people. The people who devote themselves to God will not make His authority bigger. Even there are many rebellious people, His Majesty and Authority will not be decreased. God Almighty obliges praying due to His Endless Love to people. Praying is absolutely people's need since they were created to pray, from which they get their own benefits. Praying is the only way to be safe in the world and the hereafter.

It is generally known that praying can make heart quiet and peaceful. If there is only profit loss trade, it can be concluded that people will get more benefits while God will get nothing (since He owns anything). The count of 'praying trade' is like people do Dhuba pray for the sake of getting a car, a house or others. It is not wrong, but this is normal.

In a higher maqam, praying concept is not just an obligation or necessity, but it is more to love and serious effort to have a closer relationship to The Creator. Praying only has purpose that is to get His blessings. Praying in a literal meaning is doing all obligations and keeping away from prohibitions without asking or expecting merits. Whatever it is, praying is done to get blessing from Allah and keep away from His anger.

Allah has promised the believing men and believing women gardens beneath which rivers flow, wherein they abide eternally, and pleasant dwellings in gardens of perpetual residence; but approval from Allah is greater. It is that which is the great attainment. (QS.9:72).

These days, many people only see praying from what they can see even though someone prays not for the sake of riya, other people will tend to judge from people's faith from the pray they can see. Take an example, people will judge from how long people do praying or how long surah they read when they become an Imam. The longer the stronger faith this particular person might have. Similar to people who give alms without being exposed will 
be considered as less faithful compared to those who give alms openly completed with some news.

It can be concluded that the two people mentioned above are good. Not doing the praying must be avoided since it breaks God's rules. We have to be certain that God will give His appreciation for those who pray secretly or openly. Everyone has his own way to get closer to God. Faith has its own quantity and the closeness of a person to God has its own levels. God is the only judge here.

Whatever the people choose to hide or expose their pray, let's just expect that they have good intention (for example being a role model for those who expose their pray). Teaching or giving example in praying, especially mahdah pray, is quite necessary since it needs some good preparations and procedures so that people can pray orderly and respectfully.

In education department, the need of mastering two kinds of praying is clear from one of the purposes which students from Perguruan Tinggi Agama Islam (PTAI) want to achieve. Take an example, IAIN Salatiga expects that its graduates have competence to apply and teach mabdah and ghairumabdab praying in rabmatanlilalamin.

International Class Program (ICP) IAIN Salatiga has a program to gather and sharpen the 'super' students to get more knowledge to be applied in the society. The level of God's faith is absolute. It will be much better if the alumni have brains and master another language. It can be imagined that they will give great impacts in the future. In short, one characteristic from International Class Program is to master Arabic and English. The students get their lessons using both languages. One examination they have to go through is praying. Therefore, the students are required to master at least another language. Students are required to explain and teach praying in English. It cannot be denied that students' backgrounds are various: pesantren alumni, Madrasah Aliyah or general schools. Hence, the SIC students must take test and hard selections; it is not a guarantee that they will pass the praying test easily. That's why praying education is necessary for them. 
There is a burden for PTAI students in the society since the alumni are considered as religion and praying experts. The burden gives them difficulties since they have higher expectations from the society. They have a dilemma when they want to study religion actively. Take an example when someone wants to do Gerhana pray, there must be some sarcastic comments from his surroundings since he is a PTAI student. It happened because students of IAIN, especially international class program are considered religion leaders. It is unavoidable to get sarcastic comments if they don't know things related to pray.

It is a common phenomenon to happen to many Muslims outside PTAI who want to study how to pray. From a short observation, it can be concluded that Muslims are embarrassed to ask about how to pray since the society will label them as a false Muslim. For that reason, short videos take a very important role. When they cannot ask directly to other people, they can access YouTube or other sites that provide how to pray so that they can study it by themselves properly. They don't need to worry for their lack of knowledge about praying procedures anymore.

Discussing about SIC students, they are obliged to study 'more' than regular students, so that's why they have great burden. Some non-daily prays can be their burden, for example tasbih pray, Istisqa pray, etc. Therefore, they need some alternative ways so they can have fun and motivation.

Combining praying procedures and study English can be realized from the video that will be produced in this research. By using Research and Development, it will be observed what praying procedures they need. Then the video with English and Indonesian subtitles will be produced. At the end, the video will be validated by some experts.

Later in class, the use of the video will depend on the lecturers on how to teach praying procedures. When the final video is used, the lecturers should insert this video in their teaching materials that can create fun atmosphere in class.

There are three problem formulations, how to identify the process of praying tutorial video in English that SIC-IAIN Salatiga 
students need? How is the process of praying tutorial video in English for students of SIC-IAIN Salatiga? How is the process of validating the final praying video tutorial in English? How is students' perception towards the video?

\section{The Description and Kinds of Religious Praying In Islam.}

In etymology, praying or is derived from Arabic language "abidaya'budu-abdan-ibaadatan'. Ibadah or praying means obedient, subservient and humble. Those have almost similar meanings. The people who are obedient, subservient and humble in front of God are called 'abid'. 'Abid' means those who prays or prayer.

The scope of praying in Islam has many descriptions. When people do something good for themselves or others as stated in rules is called praying in Islam. The rules are 1). The practice done in praying is required as stated in syara' rules and not against them. If the practice is against the rules, it won't be considered as praying practice. 2). All the practices in praying have good intentions. It means that the practices are done for the sake of their own goodness, to gratify their family or to give benefits for others and the universe. 3). The practices in praying are done beautifully as stated by Rasulullah SAW: "God loves to see everyone of you makes something by gratifying it" (Muslim) 4). When they do the practices in praying, it is essential to do them according to syara' rules and their boundaries. They are not to do something cruel, treacherous, cheating, oppressive and seizing other people's belongings. 5). They are not to ignore obligatory practices such as shalat, zakat, and others.

Looking at the above mentioned, the scope of praying has many descriptions. Muslims have to do the practices in praying according to their ability and power to get God's blessings.

Praying is divided into two, they are mahdob and ghairumabdoh praying(Shihab, 2003:356). The first is Mahdhoh praying. It is a practice that has purpose to have a good relationship between a person and Allah SWT. The principles in mahdhoh praying describes that all practices are permitted unless there are 
rules against them. In this kind of practice, Allah disallows some creativity since $\mathrm{He}$ is the One who has it. People don't have any choices but being obedient and subservient to the rules. Some practices belong to mahdhoh are sholat, fasting, hajj, tayamum, umrah, etc. the second is Ghairumahdhoh. It is a practice which people do to have good relationship with other people. It can be considered as muamalah.

\section{English Learning}

Brown (2000: 7) stated that learning is an activity to obtain certain knowledge about something through experience or instructions. The definition stated: Learning is a relatively permanent change towards people in their attitude and a result of strong practice (Kimble \& Garmezy, 1963: 133quoted by Brown, 2000: 7). Further, Brown described learning definition as follow: 1) Learning is an acquisition or obtaining, 2) Learning is information or creativity storage 3) Retention process that involves in storage, memory and cognitive organization, 4) Learning involves being active, self awareness on what happen in and outside, 5) Learning is relatively permanent but easily forgotten, 6) Learning involves in some practices, the strong practice, 7) Learning is an attitude change.

Some theories have been developed in learning a foreign language or acquisition that has close relationship with general theories. Fauziati (2016) has summarized some learning principles to study a foreign language like behaviorism, cognition, human and constructivism. Knowing that learning a language is only to learn the definition of the language, but it is also related to strategies and learning methods which are possible to use. Some learning strategies of the students can be identified and taught for the incompetent students. It has great potentials to improve the development of a language class. A foreign language teacher can teach the students about how to apply learning strategies in class in various ways and how to develop the strategies to be more creative in teaching a language (O'malley and friends, 1985: 552-553). 


\section{Multimedia and Its Use in Class}

The media is derived from Latin language and it is a plural form from medium. Literally, it means mediator. Media is any forms that can be used to deliver a message from a sender to recipient that can stimulate thought, feeling, attention and interest of students in their learning process (Sadiman et al, 2002). Generally, multimedia involve graphic combination, texts, sound, video, and animation. The combination is a unity that displays information, message, or learning materials. The concept of combining automatically needs some hardware tools and a computer. Multimedia has a purpose that is delivering information in a fun, interesting, easy and clear way. (Suyanto, 2003).

One of the media is video without replacing teachers' roles as a teacher. It is a supplementary tool that can create more fun atmosphere; and can be one real idea to teach in class using technology-based media (Agodini, Dynarski, Honey, and Levin, 2003)

The importance of using video in teaching a foreign language is in accordance to communicative learning theory in all education institutes around the world. Some experts have stated that media has roles on improving learning process. Beside discussing about the use of video and its communicative based- learning (Cummins, 1989; Ciccone, 1995 di Bal-Gezegin, 2014), video has animportant role in culture. The use of the video as a source of language and culture target has resulted in innovation new effective teaching. Quoted from Coniam (2001)Bal-Gezegin, (2014), there are other reasons why video has become an interesting topic in a language class. Video represents contexts and discourse (Geddes dan White, 1978 in Bal-Gezegin 2014), paralinguistic features (Stempleski dan Arcario 1992 in Bal-Gezegin 2014) and it can be used as a scoring source in a language class (Brett, 1997 di Bal-Gezegin 2014).

The pluses of a video are have moving features and visual elements together with sound, it will improve students' understanding on the materials they are learning since they both listen and watch. (Harmer, 2001).Mayer (2001) explained that watching audio visual media looks like a passive activity, but actually audio visual media is 
a high cognitive activity that can be considered as an active learning process. Mayer (2001) proved that video can make students get their understanding in a language.

\section{Reseacrh Methodology}

The research is a developing research adopting from Borg and Gail (1983) and Sukmadinata modified it (2005). The research development is to develop and validate some products used in education, it is not to create a new theory or develop the existing theory. The development research used in this research has three steps: (1) Preliminary study (2) Development Model (3) Model Test.

The following image is development model in praying tutorial video in English.

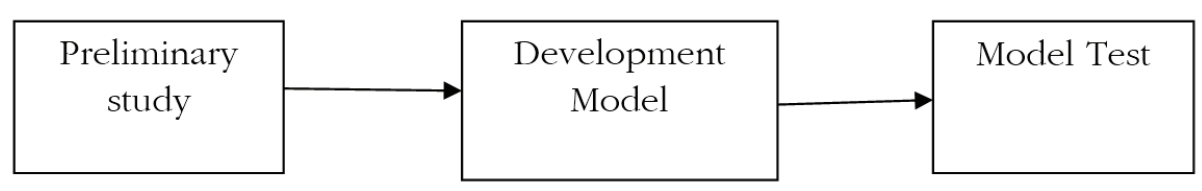

\section{Image 1.}

Development model in praying tutorial video in English

Sampling

Sample used in this research is students from special program majoring in Communication and Islam Broadcasting in IAIN Salatiga. There are 35 students in a class. Sampling method used is sampling purposive method. The purpose of using the students from the program in this research is due to the portion of getting English and Arabic language is bigger than regular programs. The video is expected to be beneficial for the students to prepare praying test as one of the requirements to join munaqosoyah test.

\section{Data Analysis Technique}

Data used in this research is qualitative and quantitative data. Quantitative data was obtained by distributing questionnaire 
containing the material quality eligibility and multimedia quality eligibility. The responses from the questions will be made into quantitative based on likert.

In addition to distributing questionnaire, interview was also conducted to get qualitative data. The interview is expected to give results in a form of suggestions and comments for improvements from the experts and the users. Suggestions and comments are required to know which parts of the video need improvements to get maximum quality eligibility. The process of qualitative data analysis is done by editing, coding, tabulations, validity test, reliability, and descriptive statistical analysis.

\section{Research Result}

Identify the process of praying tutorial video in English that SIC-IAIN Salatiga student's need

The result of the video is identified by using specified category. The category was then processed statistically by using SPSS program. The result of SPSS program is a group of students' perceptions towards the praying tutorial video in English.

Table 1.

\section{The Criteria of Praying Tutorial Video in English}

\begin{tabular}{|c|c|c|c|c|c|c|c|c|}
\hline & Material & $\begin{array}{l}\text { _Video } \\
\text { concept }\end{array}$ & Actors & Subtitle & Repetition & Duration & $\begin{array}{l}\text { Freeze } \\
\text { framing }\end{array}$ & $\begin{array}{l}\text { Students' } \\
\text { participation }\end{array}$ \\
\hline Valid & 16 & 16 & 16 & 16 & 16 & 16 & 16 & 16 \\
\hline \multicolumn{9}{|l|}{$\mathrm{N}$} \\
\hline Missing & 0 & 0 & 0 & 0 & 0 & 0 & 0 & 0 \\
\hline Mean & 4.01 & 3.88 & 4.03 & 3.84 & 3.81 & 3.81 & 4.25 & 3.94 \\
\hline Median & 4.00 & 4.00 & 4.00 & 4.00 & 3.67 & 4.00 & 4.00 & 4.00 \\
\hline Mode & 4 & 4 & 4 & 4 & 4 & 4 & 4 & 4 \\
\hline $\begin{array}{c}\text { Std. } \\
\text { Deviation }\end{array}$ & .549 & 1.057 & .763 & .598 & .412 & .911 & .577 & .854 \\
\hline
\end{tabular}




\begin{tabular}{|c|c|c|c|c|c|c|c|c|}
\hline Skewness & -.030 & -1.368 & -.376 & .160 & 1.433 & -.797 & .000 & -.605 \\
\hline $\begin{array}{c}\text { Std. } \\
\text { Error of } \\
\text { Skewness }\end{array}$ & .564 & .564 & .564 & .564 & .564 & .564 & .564 & .564 \\
\hline Kurtosis & -.263 & 2.610 & -.356 & -.647 & 4.050 & .412 & -.066 & .321 \\
\hline $\begin{array}{l}\text { Std. Error } \\
\text { of Kurtosis }\end{array}$ & 1.091 & 1.091 & 1.091 & 1.091 & 1.091 & 1.091 & 1.091 & 1.091 \\
\hline Range & 2 & 4 & 3 & 2 & 2 & 3 & 2 & 3 \\
\hline Minimum & 3 & 1 & 3 & 3 & 3 & 2 & 3 & 2 \\
\hline Maximum & 5 & 5 & 5 & 5 & 5 & 5 & 5 & 5 \\
\hline
\end{tabular}

Table 2.

Statistic Guidance to Take the Criteria of Tutorial Video

\begin{tabular}{cc}
\hline Value range & Identification result \\
\hline $4,00-5,00$ & Video criteria must be applied \\
$3,00-3,99$ & Video criteria can be applied \\
$2,00-2,99$ & Video criteria can or cannot be \\
$1,00-1,99$ & applied \\
$0,00-0,99$ & video criteria cannot be applied \\
& video criteria must not be applied \\
\hline
\end{tabular}

The result of the video criteria was determined by the statistic result (Table 1) it has been adjusted to the statistic guidance to take the criteria. (Table 2) above was specified after value range being calculated based on the statistic.

In the first category related to students' need of praying material, SPSS result showed that the average is about 4,01. The number showed positive response on the choice of praying materials students want to study in English. In conclusion, materials of worship procedures can be learned in English lesson.

The second category related to video identification video as a media to study praying procedures in English. The average 
number is 3,88. The number showed that students didn't give negative responses towards the video. But the result also showed that students didn't really need the praying tutorial video in English. Nevertheless, it can be concluded that the 3,88 result showed that the video can be used.

The third category related to Actors Criteria in praying tutorial video in English showed that SPSS result is 4,03. The result showed that the video about to be applied would involve not more than three Indonesian people.

The fourth category related to Subtitle format in the praying tutorial video in English showed that SPSS result is 3,84. The number showed that students didn't give negative responses to the given subtitle. The result also showed that students didn't give positive responses to the given subtitle. It can be concluded that the video will be produced using English subtitle, without Indonesian subtitle.

The fifth category related to Scenes Repetition Format in the praying tutorial video in English, the statistic result showed that the average number is 3,81. Judging from the result, video will apply repetition in some praying practice scenes, for example doing Subub pray that has two rakaat and each rakaat has sujud and ruku' repetition. Furthermore, the video will facilitate some access for students to watch using YouTube media.

The sixth category related to Duration format for praying tutorial video in English, the statistic result showed the average number 3,81. It showed that the video students need is short video. The seventh category related to Freeze Framing for praying tutorial video in English showed the average number 4,25. That's why, the video will apply freeze framing video.

The eighth category related to Level of Students' Participation in praying tutorial video in English, the result showed the average number 3,94. The positive responses resulted in video identification the students need, that is involving students as the actors in the video.

From the statistic results with some suggestions from students, it can be concluded that praying tutorial video has some criteria to 
produce: 1) The theme of the video is praying procedures especially how to do shalat in English, 2) Video applied will involve not more than Indonesian actors. 3) Video will use English subtitle without Indonesian subtitle considering the short duration. 4) Video will apply some repetitions in some necessary scenes, for example doing Subub pray that has two rakaat and each rakaat has sujud and ruku' repetition. 5) The video will facilitate some easy access for students to watch using YouTube media. 6) The video will have short duration. 7) The video will use freeze framing concept. 8) The video will involve students as the actors.

\section{The process of the video production for SIC-IAIN Salatiga students}

Based on the video identification, students give positive responses to be the actors in the video. So, the video production involves the students. Some suggestions were given to the students before and after shooting. The production process has been through the process of pre-preparation before. Script is the first preparation. Video script was written by some experts together with some English teachers and actors. Involving the actors is crucial since they have significant roles in the effective production process.

Determining the limit of the video duration is the second preparation. The maximum duration is 5 minutes. The purpose is to make teachers have interaction with students after recording. The short duration will also make a room of possibility to repeat the scenes when the production process happens. Repeating some scenes in the short video aimed to maximize the English text understanding since it needs some time to do so.

The third preparation is choosing the actors who will play in the video. The actors must be from SIC majoring in Communication and Islam Broadcasting. The actors must be the ones with good pronunciation to give a good example.

Deciding the setting is the fourth preparation. The preparation process is conducted in college mosque where students learn how to make effective and efficient video. The setting was decided with some consideration not to disturb the praying process. Besides that, 
the production is not to disturb the time when people do their pray.

The fifth preparation involves in collecting participants like camera crew and video editor. The crew used some camera in turn. That's why, in this step, it is necessary to gather some people who are good at handling the camera.

The sixth preparation is gathering the tools needed in the video production, like Canon6D, 60D, 5D, XF and Sony handy camera. Each camera needs at least 3 lamps completed with tripod and microphone to get good audio.

The last preparation is actors' costume. The costume is decided according to the plot of the story. When some additional costume is needed, there must be some more budget.

The process of final product validation of Praying Tutorial Video in English?

The validation was obtained by applying open and closed questionnaire to be identified by the praying experts.

Table 3.

Video Validation Result

\begin{tabular}{llll}
\hline Category & $\begin{array}{c}\text { No } \\
\text { questionnaire }\end{array}$ & $\begin{array}{c}\text { Questionnaire } \\
\text { statements }\end{array}$ & $\begin{array}{c}\text { Validation } \\
\text { result }\end{array}$ \\
\hline & 1 & $\begin{array}{l}\text { It is necessary for } \\
\text { students of Islamic } \\
\text { university to learn } \\
\text { Islamic material. }\end{array}$ & $\begin{array}{l}\text { 'Strongly agree'. } \\
\text { It shows that } \\
\text { praying material } \\
\text { is important for }\end{array}$ \\
$\begin{array}{l}\text { Salidation } \\
\begin{array}{l}\text { on the } \\
\text { importance } \\
\text { of praying } \\
\text { materials }\end{array}\end{array}$ & $\begin{array}{l}\text { One of the important } \\
\text { Islamic materials is } \\
\text { praying materials } \\
\text { since it is related } \\
\text { to students' daily } \\
\text { activities. }\end{array}$ & $\begin{array}{l}\text { It important } \\
\text { to understand } \\
\text { the praying } \\
\text { material related } \\
\text { to daily praying } \\
\text { implementation. }\end{array}$ \\
& 2 &
\end{tabular}


Validation on the important praying materials in English class.

Validation on the video as a supplementary tool to learn praying practices using English

Validation on material relevance and tutorial video.
Islamic materials like praying lessons is necessary to learn I $n$ English class

'Doubtful' In this point, the validation didn't give satisfactory responses if the praying lesson is taught in English class..

It is recommended to use video to learn English so that students can speak English fluently.

Students can learn Praying lesson is
necessary to study in English class since it is easy to learn for students from international class program. how to do praying practices in English using video.

\footnotetext{
'Agree'

The result showed that the tutorial video content in English is appropriate with the praying materials.
} 
Validation on the actors

Validation on video format
8 involve Indonesian students to make it easier to understand.

The video is considered effective if it involves one to three actors.

'Doubtful' The result showed that video can be developed by involving actors other than the students.

\author{
'Agree' \\ The number of \\ actors in the \\ video is not \\ more than three \\ people.
}

'Strongly agree' An effective The video can involve students as the actors. video involves students in the production process.

\section{'Disagree'}

The use of bahasa Indonesia is not

The result showed that Bahasa Indonesia is necessary to add in the video.

\section{English Subtitle} is strongly recommended
'Agree'

The result showed that English subtitle is appropriate. 
12

13

14

on video

repetition

format.
15

$\begin{array}{ll} & \text { 'Agree' } \\ \text { The video } \\ \text { Rcenes is needed } & \begin{array}{l}\text { already has } \\ \text { repetition } \\ \text { format. }\end{array}\end{array}$

It is necessary to repeat in some parts of the scenes (for example: sujud part is repeated twice, and tasyahud is repeated twice, etc)

It needs one repetition in each scene (for example, sujud scene is repeated once, tasyahud scene is repeated once, etc)

The video will be easier to understand if the elements of 'scene repetition' is broadcast after all scenes have been broadcast (from takbir to tabiyat), then it will be repeated.

The video of praying procedures in English needs repetition in every scene (for example: repetition in sujud scene and after tabiyat, all scenes will be repeated)

\author{
'Agree' \\ It can be \\ concluded that \\ number of \\ repetitions in \\ some parts of \\ the scenes is \\ effective. It can \\ be repeated \\ once or twice. \\ Essentially, in \\ sujud scene, it \\ is repeated only \\ once. The video \\ meets the criteria \\ requirements
}

\section{'Disagree'}

The repetition of the video from beginning is not effective since it is considered exaggerating. The result has met the criteria requirements.

'Strongly Agree' The video has met the criteria requirements in repeating each scene.. 
Validation on video access.

Validation on video duration
Validation on freeze framing.
The video needs an access to be played outside class (for example, YouTube, television, etc).

Video of praying procedures is not effective if it has more than 15 minutes.
'Agree'

Video can be broadcast using mass media.

'Disagree'

Video duration doesn't guarantee the effectiveness of the video. It needs clear and effective content no matter how long the duration of the video is.

The parts of praying tutorial video in English must have freeze framing concept so that the students can understand the content of the video (freeze framing: the paused scenes)

\author{
'Agree' \\ The result of \\ the video is \\ appropriate to \\ freeze framing \\ concept (the \\ paused scenes)
}

The validation result above is completed with some evaluation and suggestions to improve the content of the video. From the first question in questionnaire, 1) after watching the praying tutorial video in English, which part do you think students can understand? Experts said that students will understand most of the video. Some terms need stressing, for example: bent down (ruku'). Ruku' can be put between parentheses.

The second questions of the questionnaire, 2) After watching the praying tutorial video in English, which part do you think 
students can't understand? Experts said that the video needs some terms that have to be explained in details/ for example in recite part: "rabbighfirlii warhamnii.. wa fuanni". It needs some detailed explanations including the meaning of the part in English.

The praying material in the video should represent a mukmin who is obedient and subservient in doing his praying practice. As the further validation is aurat as the component representing a mukmin. The third question, 3) What things are not to display in the video so that it will be appropriate in praying material? Experts said that the main point of an obedient and subservient mukmin is from the aurat that needs to pay attention to.

Written explanation about essential principles (rukun) and condition (syarat) are the answers from the experts for question number four, 4) What are the things necessary to improve from the praying tutorial video in English? Essential principles and condition are things people must know before doing the praying. In the video, it is essential for someone to do wudlu before doing the praying or clean from excrement (najis). Eventhough the activity is conducted very shortly, but it is the condition of a praying to be accepted by God. A scene of someone facing qiblat before pray is displayed, too. The audience of the video can see both the scenes and read the written explanation in the video.

The last question, 5) What are the video criteria appropriate to be used in English lesson? Suggestions from the experts are delivered in their statements stated that an effective video has less than 30 minutes, it has to be short, compact and knowledgeable.

As a whole, validation result proved that: 1) praying lesson is essential for students of SIC majoring in Communication and Islam Broadcasting (CIB) since the material is related to students' praying implementation, 2) Praying tutorial video helps students learn English, 3) The content of praying tutorial video is appropriate to the praying material, 4) Video can be improvised by involving other actors than students 5) An effective video involves not more than three actors. 6) The use of Bahasa Indonesia is essential in the video. 7) The concept of freeze framing in some scenes is effective. 8) The video is proper to be accessed by mass media. 9) The duration of 
the video is quite effective, more than 30 minutes. 10) Some terms in the video need stressing and detailed explanation. 11) Aurat is the main component representing a mukmin in the video. 12) $\mathrm{s}$ written explanation about essential principles and condition should be displayed in the video.

Students'perception towards the video?

Table 4.

\section{SPSS Result to know students perception towards the video}

Statistic 2

\begin{tabular}{|c|c|c|c|c|c|c|c|c|c|}
\hline & & $\begin{array}{c}\text { Material } \\
\text { perception }\end{array}$ & $\begin{array}{l}\text { Under- } \\
\text { standing }\end{array}$ & $\begin{array}{c}\text { Actors } \\
\text { perceptions }\end{array}$ & $\begin{array}{c}\text { _subtitle } \\
\text { perception }\end{array}$ & $\begin{array}{l}\text { Repetition } \\
\text { perception }\end{array}$ & $\begin{array}{c}\text { Duration } \\
\text { perception }\end{array}$ & $\begin{array}{c}\text { Concept } \\
\text { perception }\end{array}$ & $\begin{array}{c}\text { Involvement } \\
\text { perception }\end{array}$ \\
\hline \multirow{2}{*}{$\mathrm{N}$} & Valid & 15 & 15 & 15 & 15 & 15 & 15 & 15 & 15 \\
\hline & Missing & 1 & 1 & 1 & 1 & 1 & 1 & 1 & 1 \\
\hline \multicolumn{2}{|c|}{ Mean } & 4.17 & 4.07 & 3.97 & 3.63 & 3.82 & 3.40 & 4.33 & 3.87 \\
\hline \multicolumn{2}{|c|}{ Median } & 4.00 & 4.00 & 4.00 & 3.50 & 3.67 & 4.00 & 4.00 & 4.00 \\
\hline \multicolumn{2}{|c|}{ Mode } & 4 & 4 & 4 & 3 & 4 & 4 & 4 & 4 \\
\hline \multicolumn{2}{|c|}{ Std. Deviation } & .488 & .607 & .667 & .611 & .554 & .986 & .617 & .743 \\
\hline \multirow{2}{*}{\multicolumn{2}{|c|}{$\begin{array}{l}\text { Skewness } \\
\text { Std. Error of }\end{array}$}} & .276 & -.505 & .346 & .765 & .349 & -.455 & -.312 & -.978 \\
\hline & & .580 & .580 & .580 & .580 & .580 & .580 & .580 & .580 \\
\hline \multirow{2}{*}{\multicolumn{2}{|c|}{$\begin{array}{l}\text { Skewness } \\
\text { Kurtosis } \\
\text { Std. Error of }\end{array}$}} & -.101 & .967 & -.755 & .108 & .247 & -1.090 & -.404 & 2.199 \\
\hline & & 1.121 & 1.121 & 1.121 & 1.121 & 1.121 & 1.121 & 1.121 & 1.121 \\
\hline \multicolumn{2}{|c|}{$\begin{array}{l}\text { Kurtosis } \\
\text { Range }\end{array}$} & 2 & 2 & 2 & 2 & 2 & 3 & 2 & 3 \\
\hline \multicolumn{2}{|c|}{ Minimum } & 3 & 3 & 3 & 3 & 3 & 2 & 3 & 2 \\
\hline \multicolumn{2}{|c|}{ Maximum } & 5 & 5 & 5 & 5 & 5 & 5 & 5 & 5 \\
\hline
\end{tabular}

The statistic table above is the result measured to know students' perception is negative or positive. The following table is the standard to measure the previous perception: 
Table 5.

The Manual to Measure Perception

\begin{tabular}{ll}
\hline Average Range value & Perception Result \\
\hline $4,00-5,00$ & Very positive \\
$3,00-3,99$ & Positive \\
$2,00-2,99$ & Quite positive \\
$1,00-1,99$ & Negative \\
$0,00-0,99$ & Very negative \\
\hline
\end{tabular}

Table 6.

Open Questionnaire Result (Students perception on the praying tutorial video in English)

\begin{tabular}{ll} 
No & Questions \\
\hline & \\
& What do you \\
& think about \\
1 & studying English \\
& without using \\
& video?
\end{tabular}

What do you think after

2 learning English without using video?

While watching the praying tutorial video in English, is there any part that interests you? If yes, which part is it?
Students' answers and perceptions

Generally, students expressed that it is difficult to understand English without using media. They stated that by saying 'it's a bit difficult', 'it's not interesting', and 'boring'. It shows that media is important in the learning process.

Generally, students said they have difficulty to learn English without video as the supporting tool. They generally said 'abit difficult', a bit interested', and 'difficult'.

However, some students give some pluses of the video to study. They said that the video helps them more focused in studying. Video is the media that helps them absorb the English lesson since it has visual image for certain terms. Some other students said that video helps them have imagination while learning a language.

Generally, students don't give negative perception on the praying tutorial video they have watched. They said there are some interesting parts in the video, like 1) takbir scene, 2 shalat movements scenes, 3) some terms not translated into English like sujud (sajda) and ruku'.. 
While watching

the video, is there any part of the video you don't understand? If yes, which part is it?

What difficulties do you find in understanding the video?

What are things need to be added to make the video more interesting?

What are things to be added to make the video easier to understand?

Does the praying tutorial video in English make you understand more?

Write down some sentences related to praying in English that you know from the video!
Generally, students decided not to give perception in this part. But, there are three students saying that they don't have any problems understanding the video. Some other students said that some unfamiliar vocabulary make them not understand the video.
Generally, students decided not to give their perception in this part. But there are some students find difficulties while watching the video swaying that there are some unfamiliar vocabulary.

Students give various perceptions on this part. But generally, students write 1) additional music in the video. 2) include inserted instruction and reference in the videoSome other students suggested 3) clear written texts 4) dialog between local and native actors 5). Indonesian translation 6). Pictures 7) animation format.

Students' perceptions are 1) unique scenes. 2) interesting opening. 3) slow pronunciation. 4) guidance book to help understand the content of the video Some other students said that the video is good enough.

Generally, students were doubtful in completing this part. They decided not to give their perception. However, some of them said that they understand the video because it involves Indonesian people. Actors were the factor that made them understand.

Generally, students mentioned the word 'prayer', even though it is not a sentence, but a word. Some other students were able to mention sentences, like: 1.) "Let's pray together, 2.) Raise your hand and say Allohu akbar. and 3.) The first, do intention. 


\begin{tabular}{|c|c|c|}
\hline 10 & $\begin{array}{l}\text { Write down } \\
\text { some vocabulary } \\
\text { you found from } \\
\text { the video! }\end{array}$ & $\begin{array}{l}\text { Generally, students mentioned the word 'prayer'. Some } \\
\text { other students could mention some words from the video } \\
\text { 1.)Praying, 2.) Intention, and 3.) giving regard }\end{array}$ \\
\hline
\end{tabular}

In short, some positive perceptions on the praying tutorial video in English based on the statistic results and open questionnaire are: 1) praying materials are essential to learn in English after watching the video (the first category, the statistic average is 4,17). 2) understanding process on praying tutorial video in English is proven judging from the level of enthusiasm and understanding results (the second category, statistic average is 4,07). 3) The actors, subtitle, scenes repetitions, duration, and freeze framing concept are effective parts to help students understand the video (average statistic is 3,97; 3,63; 3,82; 3,40; 4,33; and 3,87). 4) there are some interesting scene $s$ in the video like takbir scene, vocabulary in sholat movement, and un-translated terms in English, like sujud, (sajda) dan ruku (ruku').

\section{Conclusion}

At this point, all $\mathrm{R} \& \mathrm{D}$ process has been carried out during the research; however, the video production still has some minuses. Some suggestions, input, and improvements are worth looking forward to for a better video product. Besides that, some researchers who work on the same fields are expected to give their enlightenments in a form of deeper research development. From the research result about the praying tutorial video in English, students are expected to be capable in religion matters and general academic. Students of Islamic University who study in International Class Program don't merely study English from western sides since the video has content of Islamic teachings. Religion materials inserted in English are expected to support teaching and learning process, not only for students from international class program. It is highly expected to make the tutorial video can be effective for other Islamic institutions that 
study about Islamic teachings in English. There are some moral values from the research results. By the use of tutorial video in English and validation process, students will realize their roles as a mukmin. Students are not expected to live in this world and then die leaving their responsibility of why they were created in this world. Students are to realize that they were created to pray their God since God is the One who knows about people's creation.

\section{Bibliography}

Agodini, R., M. Dynarski, M. Honey, and D. Levin. 2003. The Effectiveness of Educational Technology: Issues and Recommendations for a National Study. Mathematica Policy Research Paper \#8936-600. Availabe on: www.mathematica-mpr.com/PDFs/edtechrec.pdf.

Bal-Gezegin, Betül. 2014. "An Investigation Of Using Video Vs. Audio For Teaching Vocabulary". Procedia - Social and Behavioral Sciences. No.143, Pg. $450-457$

Brown. 2000. Brown, D. H. 2000. Principles of language learning \& teaching. (4th ed.). New York: Longman.

Fauziati, Endang. 2016. Applied Linguistics: Principles of Foreign Language Teaching, Learning, and Researching. Surakarta: Era Pustaka Utama

Harmer, J. 2001. The practice of English language teaching (3rd ed.) Edinburgh Gate: Longman.

Mayer, R.E. 2001. Multimedia learning. Cambridge: Cambridge University Press

O'malley, J. M, Chamot, A.U., Stewner-Manzanares, G., Russo, R.P. And L. Küpper. (1985). Learning Strategy Applications With Students Of English As A Second Language. TESOL Quarterly, Vol. 19, No. 3, September 1985 
Sadiman, Arief S et al. 2002. Media Pendidikan Pengertian, Pengembangan, dan Pemanfaatannya. Jakarta: Pustekkom Dikbud dan PT.Raja Grafindo. Persada.

Sukmadinata, S. 2005. Nana, Metode Penelitian Pendidikan, Bandung: PT. Remaja Rosdakarya. 